Canadian University Music Review

Revue de musique des universités canadiennes

\title{
Kathleen M. Toomey and Stephen C. Willis, eds. Musicians in Canada: A Bio-Bibliographical Finding List. Ottawa: Canadian Association of Music Libraries, 1981, xiv, 185 pp.
}

\section{Beverly Cavanagh}

\section{Numéro 2, 1981}

URI : https://id.erudit.org/iderudit/1013755ar

DOI : https://doi.org/10.7202/1013755ar

Aller au sommaire du numéro

Éditeur(s)

Canadian University Music Society / Société de musique des universités canadiennes

ISSN

0710-0353 (imprimé)

2291-2436 (numérique)

Découvrir la revue

Citer ce compte rendu

Cavanagh, B. (1981). Compte rendu de [Kathleen M. Toomey and Stephen C. Willis, eds. Musicians in Canada: A Bio-Bibliographical Finding List. Ottawa: Canadian Association of Music Libraries, 1981, xiv, 185 pp.] Canadian University Music Review / Revue de musique des universités canadiennes, (2), 231-233. https://doi.org/10.7202/1013755ar

All Rights Reserved (C Canadian University Music Society / Société de musique des universités canadiennes, 1981
Ce document est protégé par la loi sur le droit d'auteur. L'utilisation des services d'Érudit (y compris la reproduction) est assujettie à sa politique d'utilisation que vous pouvez consulter en ligne.

https://apropos.erudit.org/fr/usagers/politique-dutilisation/ 
and prolific, producing more by far than the combined total of all other pre-Confederation sheet music publishers" (p. 93).

It would only be fair to say that Chapters 5 and 6 helped to satisfy my need, expressed at the beginning of this review, for analysis of the subject, and in Chapter 7 we are given some of the author's conclusions. It must also be said that the author has, under her own self-imposed parameters, dealt with the subject thoroughly and with care. She may be commended for having produced a reference book - the first such study of its kind-which can serve as a model for future investigations of the publishing industry in this country. In the author's own words:

It must be recognized that the collecting of early Canadian music has not been long under way. It is hoped that the present study will stimulate more interest in this field, long neglected by historians, collectors and librarians alike. It will be found most fascinating, an almost unexplored territory, which can provide an insight into so many aspects of Canadian life: social preoccupations, musical taste, legal rights, printing and publishing, marketing, patriotism and artistic expression. It is a multi-dimensional approach, both visual and aural, to a better understanding of Canada's past and, through it, a keener appreciation of its present (p. 93).

Clifford Ford

KATHLEEN M. TOOMEY and STEPHEN C. WILliS, eds. Musicians in Canada: A Bio-Bibliographical Finding List. Ottawa: Canadian Association of Music Libraries, 1981, xiv, 185 pp.

It is perhaps unfortunate for the editors that this reviewer received her copy of the Encyclopedia of Music in Canada (1981) a few days before writing this review, for one cannot help but feel that the latter will, to some extent, diminish the need for Musicians in Canada. Nonetheless, this computerized index contains references to many musicians who might not be deemed worthy of encyclopedic coverage, hence supplementing the Encyclopedia of Music in Canada. It is a marked expansion (by 1700 new entries) of the Bio-Bibliographical Finding List of Canadian Musicians (1961).

The book is in two parts: the largest section lists musicians' names alphabetically along with birth/death dates, place of birth, a keyed (two letters plus one number) summary of their musical contributions, and a key (one letter plus one number) to bibliographic sources; the second section groups names according to their musical contributions. Prefacing this body of material are an introduction, keys to musical 
contributions and sources, and a list of monographs on Canadian music and musicians. This prefatory material raises a few questions. The list of sources includes histories (Amtmann's Music in Canada: $1600-1800$ [1975] is missing), biographical dictionaries, and catalogues. One queries the omission of the Dictionary of Canadian Biography under the general editorship of George W. Brown, which Legan publication in 1967. Also not apparent are the reasons for including a selected list of monographs; while many of the important biographical publications are cited, the list is not complete, and items such as the single unpublished thesis and the one volume on native people confuse the criteria for selection.

The Key to the Musical Contributions, which attempts to summarize music-related activities, is also rather curiously organized. General categories (teacher, compiler, adjudicator) are juxtaposed with specific ones (e.g., mandolin: compiler, recorder: teacher). In contrast to the detail with which these instrument-related categories are organized, activities involving speech discourse about music (e.g., musicologist, music theorist) are only represented at the general level. Ethnomusicologists are unfairly assumed to be either folk music teachers or folk music compilers.

With regard to the two main sections of the work, one must consider a fundamental problem in the compilation of such a reference source: the criteria for inclusion/exclusion of names and for the categorization of their contributions. While the editors do not specify these criteria, the Key to Sources suggests that an all-encompassing scope - including historical and contemporary personages, classical or popular musicians - was the intention. One wonders, then, why persons included in the Encyclopedia of Music in Canada (which was not yet published but the files for which were consulted by Toomey and Willis) are omitted. The coverage of contemporary musicians cannot be expected to be complete since, in many cases, the sources used to compile the list do not include recent information. Musicians who currently work in the university network, for example, are not consistently included. (Perhaps the next edition might add current university calendars or a Canadian University Music Society faculty list to its list of sources). The inclusion of folk, popular, or ethnic musicians is random.

Both the Key to the Musical Contributions and the nature of the omissions suggest that performers and composers had higher priority than theorists and musicologists. On the other hand, the academic (analytic, historical research, etc.) contributions of many musicians who are indexed is frequently not recognized. A rather amusing illustration of this is the solitary name of Graham George in the listing of music theorists in Section 2.

In general the finding list attempts to be very comprehensive but is somewhat uneven in content and organization. Nevertheless, it 
is quite likely that names which are not to be found in other standard sources on Canadian music may appear here and so the work will, no doubt, serve a useful function for researchers, communications people, and musicians.

Beverly Cavanagh

LARRY C. LEWIS, ed. Union List of Music Periodicals in Canadian Libraries, 2nd ed. Ottawa: Canadian Association of Music Libraries, 1981, $293 \mathrm{pp}$.

This reference work represents not only an updating but a considerable expansion of the first edition of 1964 and supplement (1967). The current list of 1,783 titles as reported by the forty-five participating libraries demonstrates the expansion of music research and education in every province in Canada during the past fifteen years. As well as noting library holdings for each periodical, information about changes in title, publication or numbering irregularities are indicated. Both contemporary and historical yearbooks/newsletters/ journals are included.

The computerization of this list should allow for more frequent revisions in the future. The 1981 edition is approximately three years out of date according to the acquisitions department at the reviewer's university. While this is not an unacceptable compilation-to-publication gap, one would hope for an even smaller margin given the present state of word-processing technology.

One serious omission from the list, preceding p. 1, of participating libraries is the University of Toronto, Faculty of Music Library. The holdings of this large and important collection are indexed; hence the reader might puzzle over the frequently-cited abbreviation for this library, OTUFM.

In general, however, this is a carefully compiled addition to our reference shelves.

Beverly Cavanagh

GEORGE A. PROCTOR. Canadian Music of the Twentieth Century. Toronto: University of Toronto Press, 1980, xxvi, 297 pp.

George Proctor has recognized the long-standing need for a guide to the rapidly expanding body of Canadian contemporary music. Unlike literature, poetry and, to some extent, painting and sculpture, Canadian composition has not attained a strong public profile despite the 